\title{
Calcification of allograft and stentless xenograft valves for right ventricular outflow tract reconstruction: An experimental study in adolescent sheep
}

\author{
Willem Flameng, MD, PhD, ${ }^{\mathrm{a}}$ Ramadan Jashari, MD, ${ }^{\mathrm{b}}$ Geofrey De Visscher, $\mathrm{PhD},{ }^{\mathrm{a}}$ \\ Lindsay Mesure, $\mathrm{MSc},{ }^{\mathrm{a}}$ and Bart Meuris, $\mathrm{MD}, \mathrm{PhD}^{\mathrm{a}}$
}

\begin{abstract}
Objective: Aortic homografts were compared with pulmonary homografts in the setting of right ventricular outflow tract reconstruction in adolescent sheep. Furthermore, clinically available stentless porcine and bovine xenografts were studied as an alternative to homografts.
\end{abstract}

\begin{abstract}
Methods: In 51 adolescent sheep cryopreserved aortic and pulmonary (ovine) homografts, as well as 6 different types of clinically available stentless bioprostheses (Prima Plus, Toronto SPV, Toronto BiLinx, Freestyle, Pericarbon Stentless, and Contegra) were implanted in the pulmonary position. After 5 to 6 months, the valves were explanted and studied for structural valve degeneration by means of radiographic analysis, histology, and calcium content determination.
\end{abstract}

\begin{abstract}
Results: Pulmonary homografts calcified significantly less than aortic homografts in the wall portion. Leaflet calcification was mild, hardly detectable on radiographic analysis, and comparable between aortic and pulmonary homografts. Stentless porcine xenografts showed severe calcification in the aortic wall portion, irrespective of the antimineralization treatment. Leaflet calcification was mild and in the range of that seen in homografts. Pannus formation was present but never induced leaflet retraction or cusp immobilization. Calcification was absent in the stentless Pericarbon valve implants, but all valves showed extensive pannus overgrowth, leaflet retraction, and cusp immobilization. The Contegra valves showed wall calcification, but the leaflets were completely free of calcification and pannus.
\end{abstract}

Conclusions: For right ventricular outflow tract reconstruction, the pulmonary homograft remains the first choice. All xenografts result in either calcific degeneration or cusp immobilization. (J Thorac Cardiovasc Surg 2011;141:1513-21)

Valved homografts have become the most commonly used valved conduits for reconstruction of the right ventricular outflow tract (RVOT) because stented xenografts develop calcification, cusp tears, pannus formation, and typical cusp immobilization. ${ }^{1-4}$ Recently, there is increasing evidence in congenital heart surgery that aortic homografts also calcify but faster and more significantly compared with their pulmonary counterparts. Therefore pulmonary homografts have become the conduit of choice for RVOT reconstruction, especially in young children., However, given the relative shortage of small pulmonary homografts, it was suggested that aortic homografts still can be used in infants and older patients without compromising long-term results. ${ }^{4}$

\footnotetext{
From the Laboratory for Experimental Cardiac Surgery, ${ }^{\mathrm{a}}$ Department of Cardiovascular Diseases, Katholieke Universiteit Leuven, Leuven, Belgium; and the European Homograft Bank (EHB) International Association, ${ }^{\text {b }}$ Brussels, Belgium.

Disclosures: Authors have nothing to disclose with regard to commercial support.

Received for publication May 25, 2010; revisions received Aug 3, 2010; accepted for publication Aug 29, 2010; available ahead of print Nov 22, 2010.

Address for reprints: Willem Flameng, MD, PhD, Cardiac Surgery, University Clinic Gasthuisberg, Herestraat 49, B-3000 Leuven, Belgium (E-mail: willem.flameng@ med.kuleuven.be).

$0022-5223 / \$ 36.00$

Copyright (c) 2011 by The American Association for Thoracic Surgery doi:10.1016/j.jtcvs.2010.08.082
}

It is the first goal of the present study to compare the calcification potential of aortic versus pulmonary homografts in an experimental setting in which growth and outgrowth of the allografts do not play a role. We included a series of aortic (ovine) homografts and a series of pulmonary homografts (originating from the same donor as their aortic homograft counterparts) in our adolescent sheep model experiments. $^{6}$

On the other hand, more recently, several new types of heterografts have been developed and promoted as alternatives to homografts and stented xenografts. Compared with the older stented porcine heterografts mounted in a Dacron conduit, stentless design and antimineralization treatment render these new xenografts theoretically more suitable candidates to replace homografts than the older generation of conduits. ${ }^{6}$ Different models of stentless xenografts are commercially available and clinically used. We tested 6 of them in our adolescent sheep model: 4 of them are glutaraldehyde-fixed porcine roots, and the other 2 are glutaraldehyde-fixed bovine tissue, either pericardium or valved jugular vein. Several of these valves are treated with an antimineralization treatment, although others are not. It was the second goal of this study to compare the calcification potential of these stentless 


\section{Abbreviations and Acronyms \\ DW = dry weight \\ RVOT $=$ right ventricular outflow tract}

xenografts with that of (ovine) homografts as RVOT implants.

\section{MATERIALS AND METHODS Model}

Fifty-eight Lovenaar sheep between 8 and 11 months of age (weighing $44.9 \pm 6.2 \mathrm{~kg}$ ) were used in the study. The animals were bred at a special unit of the Katholieke Universiteit Leuven and procured for research through the Animalarium Katholieke Universiteit Leuven. The experiments were approved by the Ethics Committee of the Katholieke Universiteit Leuven.

Seven animals were male and used as donors for allografts. They were premedicated with ketamine (10-20 mg/kg administered intramuscularly), and anesthesia was induced with increasing concentrations of isoflurane in oxygen. After heparinization $(3 \mathrm{mg} / \mathrm{kg}$ ), they were killed with an overdose of pentobarbital (Nembutal; Ovation Pharmaceuticals, Inc, Deerfield, Ill) and $\mathrm{KCl}$ intravenously. The pulmonary and aortic roots were excised from every sheep and cryopreserved as described below. ${ }^{7}$

Fifty-one animals were female and used as recipients for allografts or xenografts. The animals were premedicated with ketamine $(10-20 \mathrm{mg} / \mathrm{kg}$ administered intramuscularly), and anesthesia was induced with increasing concentrations of isoflurane in oxygen. Anesthesia was maintained with isoflurane in $5 \mathrm{~L} / \mathrm{min} \mathrm{O}_{2}$ and $2 \mathrm{~L} / \mathrm{min} \mathrm{N}_{2} \mathrm{O}$. A left thoracotomy was performed, and after administration of heparin $(3 \mathrm{mg} / \mathrm{kg})$, the animal was started on cardiopulmonary bypass. The main pulmonary artery was crossclamped, the native pulmonary valve was excised, and the pulmonary root was replaced with either the allograft or the xenograft. After weaning from bypass, the chest and surgical wounds were closed, mechanical ventilation was discontinued, and the animal was allowed to recover.

At 5 to 6 months after surgical intervention, according to the protocol, the animals were again anesthetized and killed after heparinization $(3 \mathrm{mg} /$ $\mathrm{kg}$ ) with an overdose of pentobarbital and $\mathrm{KCl}$ administered intravenously. The implanted bioprosthesis was excised and analyzed as described below.

\section{Bioprostheses}

Two different types of allografts and 6 different types of xenografts were implanted. The characteristics of these valves in terms of brand name, manufacturer, number of implants, donor tissue, antimineralization treatment, and tissue treatment are given in Table 1.
Allografts. The pulmonary and aortic roots from 7 donor sheep were processed by the qualified personnel of the European Homograft Bank (Brussels, Belgium). ${ }^{7}$ Exactly the same procedure of cryopreservation was followed as is used for clinically available human homografts. ${ }^{7}$ The allografts were sterilized in the antibiotic cocktail (Lincocin, Vancocin and Polymixin B) over 20 to 48 hours and cryopreserved by using liquid nitrogen with $10 \%$ dimethyl sulfoxide in Hanks' solution as a cryoprotectant, with controlled-rate freezing at $1^{\circ} \mathrm{C}$ per minute down to $-40^{\circ} \mathrm{C}$ and $5^{\circ} \mathrm{C}$ per minute down to $-100^{\circ} \mathrm{C}$. They were stored in the vapors of liquid nitrogen at a temperature of less than $-150^{\circ} \mathrm{C}$. Just before implantation, they were thawed by means of rapid temperature increase according to the European Homograft Bank protocol, and the dimethyl sulfoxide dilution was performed with isotonic solution (saline) in 4 steps of 1 minute each, decreasing the dimethyl sulfoxide concentration from $10 \%$ to less than $1 \%$.

Xenografts. Six different types of clinically available stentless bioprostheses were used (Table 1). All valves were cross-linked with glutaraldehyde. Four types (Prima Plus, Toronto SPV, Toronto BiLinx, and Freestyle) are porcine roots. The other 2 types were made from bovine tissue (ie, bovine pericardium [Pericarbon] or bovine jugular vein [Contegra]).

\section{Explant Examination}

After careful rinsing, gross examination of the explanted specimen was performed, with special attention to vegetations, cuspal hematoma, thrombosis, stiffness of the wall portion, visible calcifications, cusp retraction, tissue overgrowth (pannus), and leaflet tears and perforations.

Radiographic examinations were performed (Faxitron X-Ray, Lincolnshire, Ill), first in a horizontal plane perpendicular to the inflow-outflow axis showing the leaflets. The root was then longitudinally sectioned through the commissures, providing 3 wall portions, each containing one leaflet. The 3 sections were unrolled in a single plane, and radiographs were obtained.

Half of every section was used for calcium determination, and the rest was used for histology and further Faxitron analysis. This means that a longitudinal section (thickness of $1 \mathrm{~cm}$ ) was made, including leaflet and inflow and outflow wall portions. Because this section and the histologic sections were taken adjacently, comparison between radiographic and histologic localization of calcifications became possible (Figure 1). For histology, $5-\mu \mathrm{m}$-thick sections were prepared, showing the entire wall and the leaflet of the bioprosthesis (Figure 1). The sections were embedded in paraffin and stained with hematoxylin and eosin, Masson's trichrome stain for collagen, Von Giesson stain for elastin, phosphotungstic acid-hematoxylin for fibrin, and Von Kossa stain for calcium.

For quantitative calcium determination, half of every segment was used, which means that $50 \%$ of the valve was analyzed for calcium content. The tissue was divided into conduits and leaflets. The conduit wall was divided into outflow and inflow portions. For quantification of the calcium content,

TABLE 1. Valve types and characteristics

\begin{tabular}{|c|c|c|c|c|c|}
\hline & Valve type & Manufacturer & $\begin{array}{c}\text { No. of } \\
\text { implants }\end{array}$ & $\begin{array}{c}\text { Antimineralization } \\
\text { treatment }\end{array}$ & Tissue treatment \\
\hline \multirow[t]{2}{*}{ Ovine homograft } & Aortic homograft & European Homograft Bank, Brussels, Belgium & 7 & None & Cryopreservation \\
\hline & Pulmonary homograft & European Homograft Bank, Brussels, Belgium & 6 & None & Cryopreservation \\
\hline \multirow[t]{4}{*}{ Porcine xenograft } & Prima Plus & Edwards Lifesciences, Irvine, Calif & 8 & Tween-80 & Glutaraldehyde \\
\hline & Toronto SPV & St Jude Medical, Inc, St Paul, Minn & 5 & None & Glutaraldehyde \\
\hline & Toronto BiLinx & St Jude Medical, Inc, St Paul, Minn & 8 & $\begin{array}{l}\text { Ethanol (leaflets); } \\
\text { aluminum (wall) }\end{array}$ & Glutaraldehyde \\
\hline & Freestyle & Medtronic, Inc, Minneapolis, Minn & 7 & $\alpha$-Amino oleic acid & Glutaraldehyde \\
\hline \multirow[t]{2}{*}{ Bovine xenograft } & Pericarbon & Sorin Biomedica, Saluggia, Italy & 5 & None & Glutaraldehyde \\
\hline & Contegra & Medtronic, Inc, Minneapolis, Minn & 5 & None & Glutaraldehyde \\
\hline
\end{tabular}



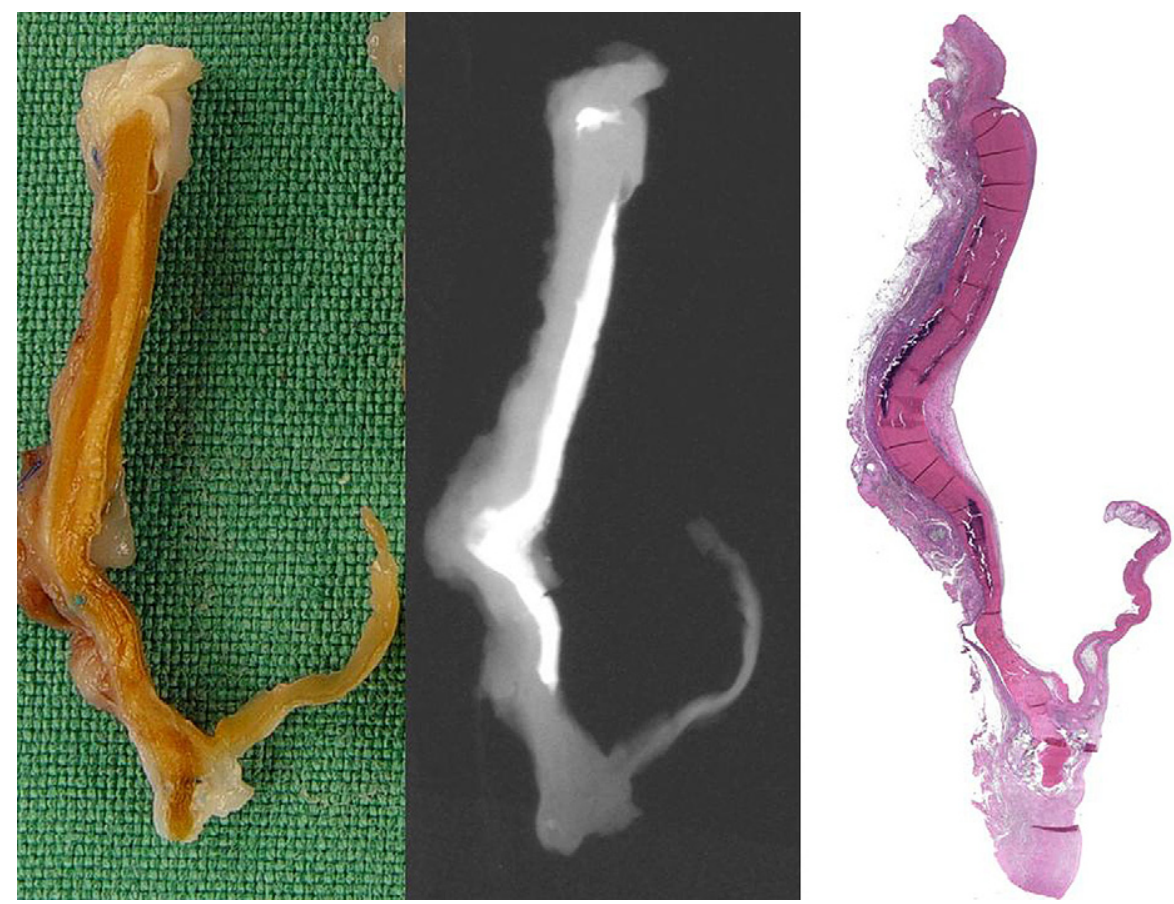

FIGURE 1. Representative images from the postexplantation processing of all valves, with standardized cutting of the valves in segments, macroscopic analysis (left panel), soft tissue radiographic analysis (middle panel), and histology (right panel).

the samples were lyophilized, weighed, and dissolved in $20 \%$ hydrochloric acid solution $(10 \mathrm{mg}$ of dried tissue $/ \mathrm{mL}$ of $\mathrm{HCl}$ ) for 24 hours. After homogenization, samples were kept at $70^{\circ} \mathrm{C}$ overnight. Samples were then analyzed with a Calcium kit (Chema Diagnostica, Monsano, Italy) and a spectrophotometer (Multiscan EX; Thermo Electron Corp, Woburn, Mass). All values are expressed in micrograms per milligram dry weight (DW).

\section{Statistical Analysis}

Because the calcium content data were abnormally distributed, nonparametric statistics were used. Results are presented as the median (minimummaximum). Comparisons among more than 2 groups were performed with a Kruskal-Wallis test. If significance $(P<.05)$ was observed, pairwise comparisons of the groups were performed with nonpaired Mann-Whitney

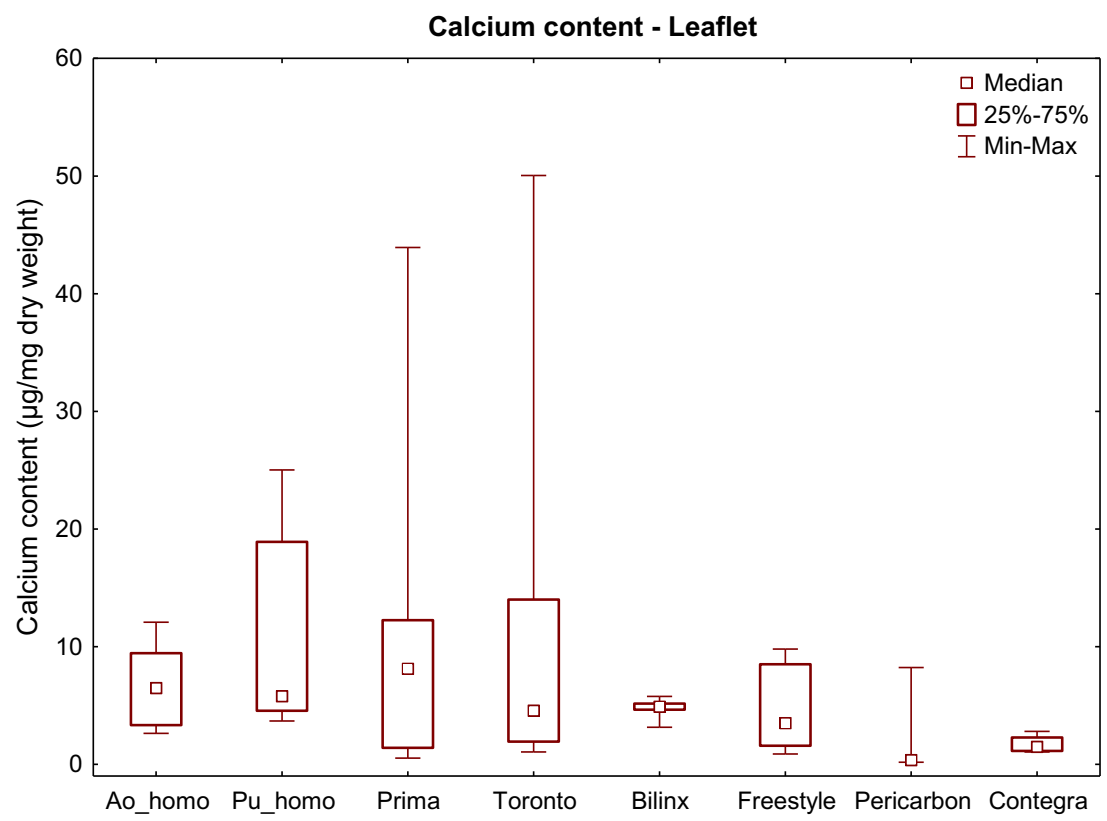

FIGURE 2. Calcium content values (median, interquartile range, and range) of leaflet tissue. Significant differences (Kruskal-Wallis testing followed by separate Mann-Whitney $U$ tests) are reported in Table 2. Ao_homo, Aortic homograft; Pu_homo, pulmonary homograft. 
TABLE 2. Statistical analysis of calcification in the leaflet

\begin{tabular}{|c|c|c|c|c|c|c|}
\hline & Prima Plus & Toronto SPV & Toronto BiLinx & Freestyle & Pericarbon & Contegra \\
\hline \multicolumn{7}{|l|}{ Ovine homografts } \\
\hline Aortic & NS & NS & NS & NS & $(>) P=.03$ & $(>) P=.01$ \\
\hline Pulmonary & NS & NS & NS & NS & $(>) P=.05$ & $(>) P=.01$ \\
\hline \multicolumn{7}{|l|}{ Porcine xenografts } \\
\hline Prima Plus & - & NS & NS & NS & $(>) P=.01$ & NS \\
\hline Toronto SPV & NS & - & NS & NS & $(>) P=.01$ & $(>) P=.04$ \\
\hline Toronto BiLinx & NS & NS & - & NS & NS & $(>) P=.008$ \\
\hline Freestyle & NS & NS & NS & - & $(>) P=.03$ & NS \\
\hline \multicolumn{7}{|l|}{ Bovine xenografts } \\
\hline Pericarbon & $(<) P=.01$ & $(<) P=.01$ & NS & $(<) P=.03$ & - & NS \\
\hline Contegra & NS & $(<) P=.04$ & $(<) P=.008$ & NS & NS & - \\
\hline
\end{tabular}

$U$ tests. In the tables all $P$ values of less than .1 are shown, and values of greater than .1 are indicated as not significant.

\section{RESULTS}

\section{Valve Calcification}

In the 3 parts of the valve (ie, the inflow tract, leaflets, and outflow tract), calcification was documented on the radiographic image (Faxitron, Figure 1) and on the histologic section (Von Kossa staining). These observations were related to the quantitative data of the calcium content measurements in the different samples. By using receiver operating characteristic analysis, it was found that calcification became detectable with radiographic analysis when the calcium content in the samples exceeded $10.6 \mu \mathrm{g} / \mathrm{mg}$ DW for the leaflets and $14 \mu \mathrm{g} / \mathrm{mg}$ DW for the wall. In the histologic sections calcification became apparent at calcium content values of $12.1 \mu \mathrm{g} / \mathrm{mg}$ DW for the leaflets and $15 \mu \mathrm{g} / \mathrm{mg}$ DW for the wall. Because calcifications in the low range (ie, $<10-15 \mu \mathrm{g} / \mathrm{mg} \mathrm{DW}$ ) were not detected by means of radiographic analysis or histology, all further analysis of calcification will be based on the calcium content data.

Leaflet calcification. The degree of calcification in the leaflets differed significantly between the different types of grafts $(P=.03$, Kruskal-Wallis test). Leaflets of aortic or pulmonary homografts calcified to the same extent (3.7 [1.5-6.9] vs 3.3 [2.1-14.3] $\mu \mathrm{g} / \mathrm{mg} \mathrm{DW}, P>.05$ ), and the level of calcification was comparable with that found in porcine stentless xenografts (Figure 2 and Table 2). Leaflets of stentless bovine xenografts calcified significantly less than those of homografts and most stentless porcine xenografts (Figure 2 and Table 2).

Wall calcification. In the inflow part, as well as the outflow part, of the graft wall, the degree of calcification differed significantly between different graft types $(P=.0003$ and $P=.0005$, respectively; Kruskal-Wallis test). The wall portions of aortic homografts calcified significantly more than those of pulmonary homografts. This was the case for both the inflow (25.5 [7.2-62.8] vs 3.9 [2.5-8.1] $\mu \mathrm{g} / \mathrm{mg}$ DW, $P=.005)$ and outflow (157.1 [106.7-205.2] vs 8.3 [1.3-38.1] $\mu \mathrm{g} / \mathrm{mg} \mathrm{DW}, P<.003)$ portions. Both the inflow and outflow tracts of the wall in aortic homografts were more calcified than that of stentless bovine xenografts and most of the stentless porcine xenografts. In pulmonary homografts these wall portions were less calcified than those in stentless porcine xenografts, and calcification was as low as that seen in stentless bovine xenografts. The results are presented in Tables 3 and 4 and Figures 3 and 4 .

TABLE 3. Statistical analysis of calcification in the inflow tract of the graft wall

\begin{tabular}{|c|c|c|c|c|c|c|}
\hline & Prima Plus & Toronto SPV & Toronto BiLinx & Freestyle & Pericarbon & Contegra \\
\hline \multicolumn{7}{|l|}{ Ovine homografts } \\
\hline Aortic & $(>) P=.02$ & $(<) P=.06$ & $(>) P=.009$ & NS & $(>) P=.03$ & NS \\
\hline Pulmonary & $(<) P=.05$ & $(<) P=.001$ & $(<) P=.04$ & NS & NS & NS \\
\hline \multicolumn{7}{|l|}{ Porcine xenografts } \\
\hline Prima Plus & - & $(<) P=.001$ & NS & NS & $(>) P=.006$ & NS \\
\hline Toronto SPV & $(>) P=.001$ & - & $(>) P=.0007$ & NS & $(>) P=.004$ & NS \\
\hline Toronto BiLinx & NS & $(<) P=.0007$ & - & NS & NS & NS \\
\hline Freestyle & NS & NS & NS & - & $(>) P=.05$ & NS \\
\hline \multicolumn{7}{|l|}{ Bovine xenografts } \\
\hline Pericarbon & $(<) P=.06$ & $(<) P=.004$ & NS & $(<) P=.05$ & - & NS \\
\hline Contegra & NS & NS & NS & NS & NS & - \\
\hline
\end{tabular}

$(>)$ or $(<)$, Calcium content data are higher or lower, respectively, in the grafts listed at the left versus those listed at the top. NS, Not significant $(P>.1)$. 
TABLE 4. Statistical analysis of calcification in the outflow tract of the graft wall

\begin{tabular}{|c|c|c|c|c|c|c|}
\hline & Prima Plus & Toronto SPV & Toronto BiLinx & Freestyle & Pericarbon & Contegra \\
\hline \multicolumn{7}{|l|}{ Ovine homografts } \\
\hline Aortic & $(>) P=.01$ & $(>) P=.001$ & NS & $(>) P=.03$ & $(>) P=.005$ & $(>) P=.02$ \\
\hline Pulmonary & $(<) P=.001$ & $(<) P=.001$ & $(<) P=.008$ & $(<) P=.01$ & NS & NS \\
\hline \multicolumn{7}{|l|}{ Porcine xenografts } \\
\hline Prima Plus & - & $(>) P=.01$ & NS & NS & $(>) P=.002$ & NS \\
\hline Toronto SPV & $(<) P=.01$ & - & NS & NS & $(>) P=.001$ & NS \\
\hline Toronto BiLinx & NS & NS & - & NS & $(>) P=.004$ & NS \\
\hline Freestyle & NS & NS & NS & - & (>) $P=.01$ & NS \\
\hline \multicolumn{7}{|l|}{ Bovine xenografts } \\
\hline Pericarbon & $(<) P=.002$ & $(<) P=.001$ & $(<) P=.004$ & $(<) P=.01$ & - & NS \\
\hline Contegra & NS & NS & NS & NS & NS & - \\
\hline
\end{tabular}

\section{Analysis of Pannus Overgrowth}

Pannus at the leaflets and cusp immobilization. Only the Contegra valves were completely free of pannus at the leaflets also at the ventricularis side. All other stentless xenografts showed pannus formation at the ventricularis side. This was most pronounced in the aortic homografts and in the Toronto BiLinx xenograft. None of the grafts showed significant pannus formation at the fibrosa side of the leaflets, with the exception of 2 stentless xenografts: the Prima valve and the Pericarbon valve (Tables 5 and 6). The Pericarbon valve was the only valve with pannus formation at both sides of the leaflets, which was so aggressive that it was associated with attraction of the cusps and adhesion of the leaflets to the conduit wall, resulting in cusp immobilization. This induced stenosis and severe incompetence of the valve. Figure 5 shows a typical example of this complication. The results are shown in Tables 5 and 7 . Pannus at the wall portion. At the inflow side of the wall portion, all homografts and stentless xenografts had pannus formation, and there was no significant difference in its incidence between valve types $(P>.05)$. The same was found at the outflow side of the wall portion with one exception: the Toronto BiLinx valve. This valve showed significantly less pannus than both homograft types, the Prima valve and the Freestyle xenografts $(P<.05)$. The results are shown in Table 5 .

\section{DISCUSSION}

Although the development of cryopreservation techniques combined with improved availability has resulted

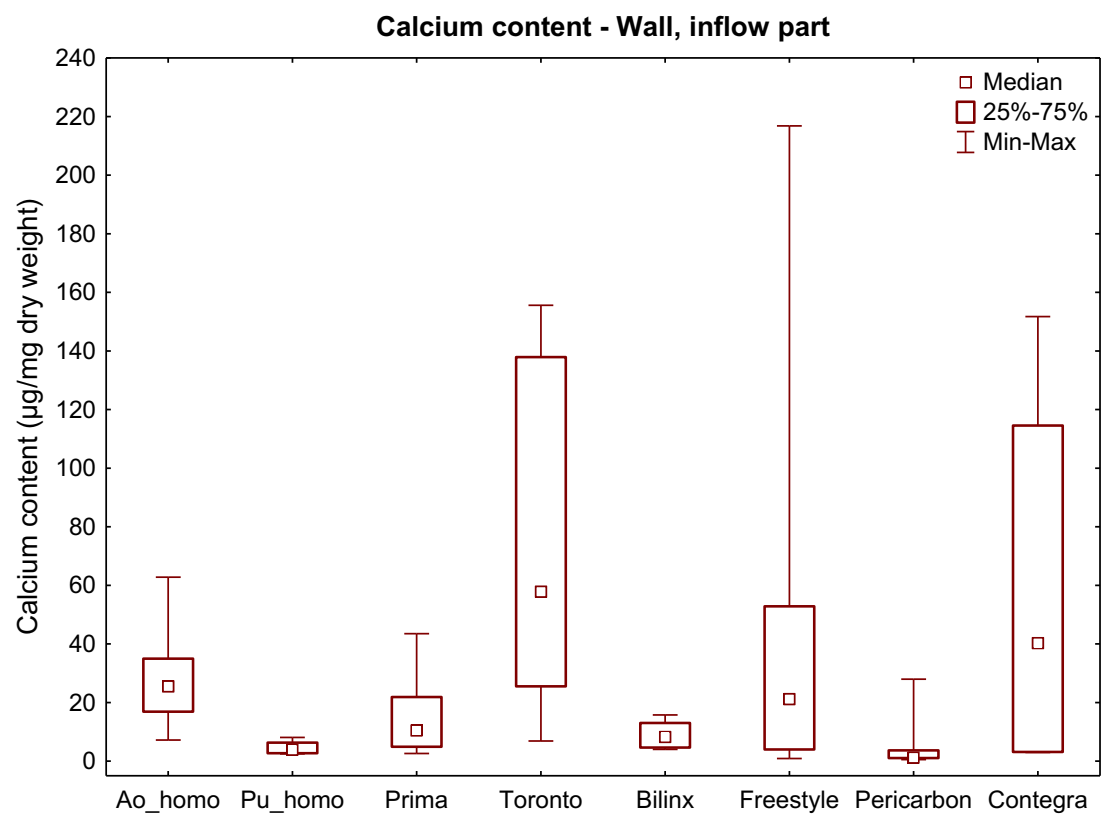

FIGURE 3. Calcium content values (median, interquartile, range and range) of wall tissue, more specifically the inflow portion. Significant differences (Kruskal-Wallis testing followed by separate Mann-Whitney $U$ tests) are reported in Table 3. Ao_homo, Aortic homograft; Pu_homo, pulmonary homograft. 


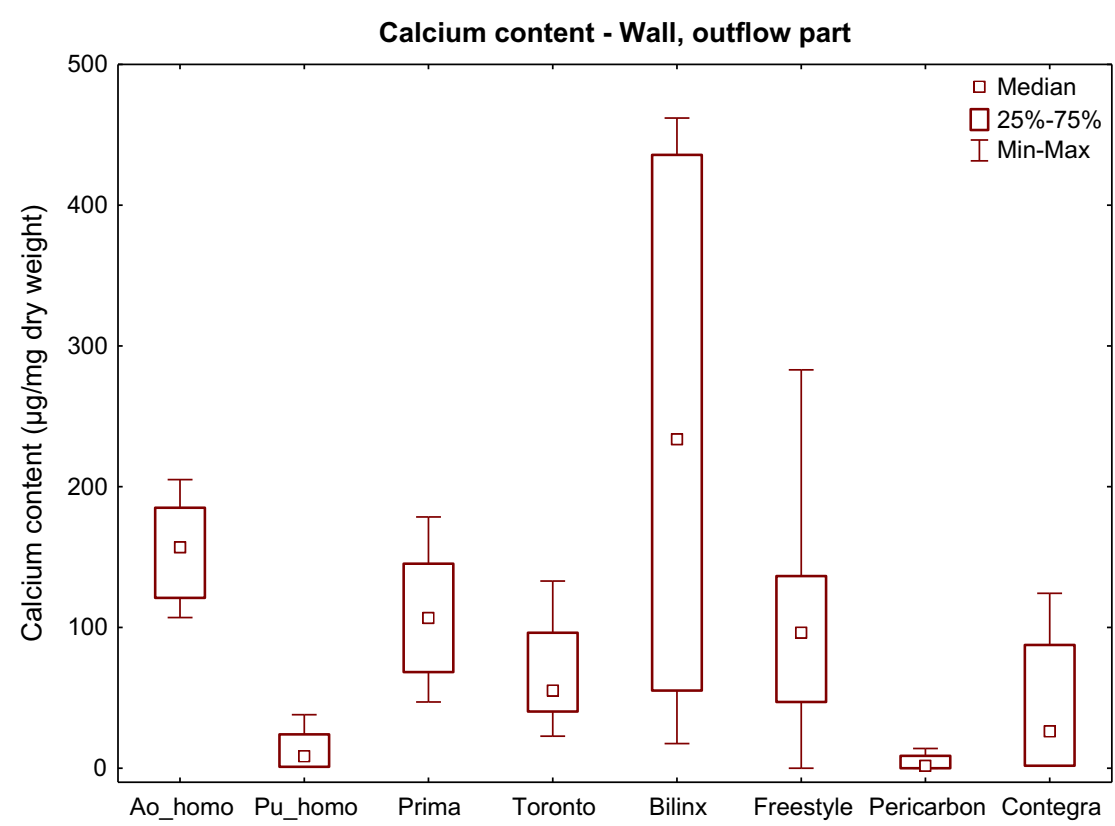

FIGURE 4. Calcium content values (median, interquartile, range and range) of wall tissue, more specifically the outflow portion. Significant differences (Kruskal-Wallis testing followed by separate Mann-Whitney $U$ tests) are reported in Table 4. Ao_homo, Aortic homograft; Pu_homo, pulmonary homograft.

in the widespread use of homografts for reconstruction of the RVOT in patients with congenital heart disease, ${ }^{4}$ their durability is limited and was shown to be adversely affected by several factors, including younger age and smaller homograft size at implantation. Outgrowth of the homograft valves appears to be an important cause of homograft failure. ${ }^{4}$ Also, the type of homograft (aortic or pulmonary) was suggested as a factor of reduced durability, ${ }^{4,8}$ although others could not confirm this. ${ }^{9}$ Size and outgrowth seem to overwhelm homograft type as a predictor of failure. ${ }^{10}$ Obviously, outgrowth results in patient-prosthesis mismatch, which plays a significant role in structural valve deterioration, as we recently showed for aortic valve bioprostheses. ${ }^{11}$ To avoid outgrowth, we tested aortic and pulmonary homografts in the RVOT position in an

TABLE 5. Incidence of pannus formation in the valve leaflets and wall portion

\begin{tabular}{lcccc}
\hline & Fibrosa & Ventricularis & Inflow & Outflow \\
\hline Ovine homografts & & & & \\
$\quad$ Aortic & $0 / 7$ & $7 / 7$ & $7 / 7$ & $7 / 7$ \\
$\quad$ Pulmonary & $0 / 6$ & $5 / 6$ & $6 / 6$ & $6 / 6$ \\
Porcine xenografts & & & & \\
$\quad$ Prima Plus & $6 / 8$ & $3 / 8$ & $6 / 8$ & $8 / 8$ \\
$\quad$ Toronto SPV & $2 / 5$ & $2 / 5$ & $5 / 5$ & $3 / 5$ \\
Toronto BiLinx & $0 / 8$ & $8 / 8$ & $8 / 8$ & $3 / 8$ \\
$\quad$ Freestyle & $0 / 7$ & $5 / 7$ & $7 / 7$ & $7 / 7$ \\
Bovine xenografts & & & & \\
$\quad$ Pericarbon & $5 / 5$ & $2 / 5$ & $5 / 5$ & $5 / 5$ \\
$\quad$ Contegra & $0 / 5$ & $0 / 5$ & $5 / 5$ & $4 / 5$ \\
\hline
\end{tabular}

experimental model of adolescent sheep. In adolescent sheep (age range, $8-11$ months), in contrast to juvenile sheep, growth slowed down already to such an extent that outgrowth and mismatch of the valve do not occur anymore. On the other hand, calcification potential is maintained in this model. ${ }^{6}$ By doing so, we could clearly show that aortic homografts calcify significantly more than pulmonary homografts. Because in our model both the aortic and pulmonary homografts originated from the same donor, the basic mechanism of this difference in calcification potential must be searched in the intrinsic difference of tissue structure between aortic and pulmonary grafts. Although we found that pulmonary homografts calcify less than aortic homografts, they still calcified to a certain extent. This was also described by Hopkins and colleagues, ${ }^{12}$ although they used a juvenile sheep model. In the clinical setting it was shown that in infants the most common indication for reoperation in patients receiving cryopreserved pulmonary valve allografts to repair their RVOTs is allograft fibrocalcification and valve insufficiency. ${ }^{13}$

For reconstruction of the RVOT in patients with congenital heart disease, allografts have the reputation of better longterm durability than xenografts. ${ }^{9,14,15}$ These observations were based on the use of stented porcine xenografts mounted in Dacron conduits or orthotopic implants of stented xenografts. In a recent study Soor and associates ${ }^{1}$ reviewed the morphologic findings in 40 cases of pulmonary site bioprostheses. This study included pulmonary valves in conduits, as well as orthotopically implanted valves. The valves were all stented valves, be they porcine or bovine 
TABLE 6. Statistical analysis of pannus formation on the fibrosa side of the leaflets

\begin{tabular}{|c|c|c|c|c|c|c|}
\hline & Prima Plus & Toronto SPV & Toronto BiLinx & Freestyle & Pericarbon & Contegra \\
\hline \multicolumn{7}{|l|}{ Ovine homografts } \\
\hline Aortic & $(<) P=.007$ & NS & NS & NS & $(<) P=.001$ & NS \\
\hline Pulmonary & $(<) P=.01$ & NS & NS & NS & $(<) P=.002$ & NS \\
\hline \multicolumn{7}{|l|}{ Porcine xenografts } \\
\hline Prima Plus & - & NS & $(>) P=.007$ & $(>) P=.007$ & NS & $(>) P=.02$ \\
\hline Toronto SPV & NS & - & NS & NS & NS & NS \\
\hline Toronto BiLinx & $(<) P=.07$ & NS & - & NS & $(<) P=.001$ & NS \\
\hline Freestyle & $(<) P=.07$ & NS & NS & - & $(<) P=.001$ & NS \\
\hline \multicolumn{7}{|l|}{ Bovine xenografts } \\
\hline Pericarbon & NS & NS & $(>) P=.001$ & $(>) P=.001$ & - & $(>) P=.008$ \\
\hline Contegra & $(<) P=.02$ & NS & NS & NS & $(<) P=.008$ & - \\
\hline
\end{tabular}

pericardial valves. All these explants had 3 pathologic features in common: cusp calcification in $80 \%$ of the valves, tears in $47.5 \%$, and pannus or host tissue overgrowth in $97.5 \%$. Cusp immobilization by pannus overgrowth and leaflet retraction was common in patients younger than 30 years and typically contributed to valve stenosis and incompetence. It was also recognized by others that stented porcine valves calcified, and when they were included in a conduit, the Dacron graft developed a pseudointimal peel that could result in stenosis of small-diameter conduits. ${ }^{4,14,15}$

The development of stentless xenografts opened new perspectives because the design of these xenografts resembles that of homografts. Recently, the Freestyle porcine aortic root has been used clinically for RVOT reconstruction in children. Short-term and midterm results are encouraging, showing a low incidence of pulmonary insufficiency and minimal pressure gradients across the RVOT. ${ }^{16-19}$ However, isolated cases of leaflet stenosis were reported, ${ }^{17}$ eventually leading to reoperation. ${ }^{19}$ In one report the peak pressure gradient across the Freestyle valve was followed over time and was shown to increase from $12.1 \pm 11 \mathrm{~mm} \mathrm{Hg}$ at discharge to $24.1 \pm 20 \mathrm{~mm} \mathrm{Hg}$ after 51 months. ${ }^{19}$ Such findings raise questions about the longterm durability of these stentless xenografts. Our experimental data in the accelerated calcification model of chronic sheep implants show that leaflets of stentless
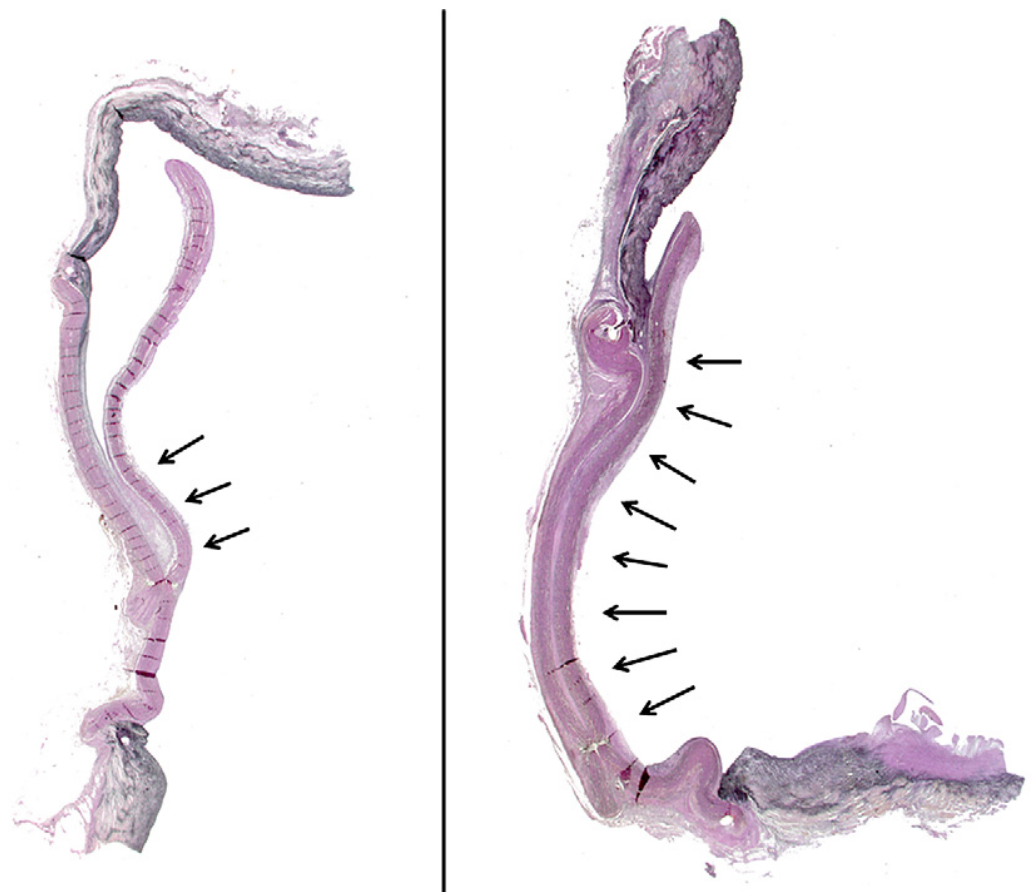

FIGURE 5. Representative histologic examples from explanted stentless Pericarbon valves. Different degrees of pannus formation with cusp immobilization are shown. Left panel, Moderate pannus formation with immobilization of the lower third of the cusp; right panel, severe pannus with complete cusp retraction. 
TABLE 7. Statistical analysis of pannus formation on the ventricularis side of the leaflets

\begin{tabular}{|c|c|c|c|c|c|c|}
\hline & Prima Plus & Toronto SPV & Toronto BiLinx & Freestyle & Pericarbon & Contegra \\
\hline \multicolumn{7}{|l|}{ Ovine homografts } \\
\hline Aortic & $(>) P=.02$ & $(>) P=.01$ & NS & NS & $(>) P=.04$ & $(>) P=.001$ \\
\hline Pulmonary & NS & NS & NS & NS & NS & $(>) P=.01$ \\
\hline \multicolumn{7}{|l|}{ Porcine xenografts } \\
\hline Prima Plus & - & NS & $(<) P=.02$ & NS & NS & NS \\
\hline Toronto SPV & NS & - & $(<) P=.03$ & NS & NS & NS \\
\hline Toronto BiLinx & $(>) P=.02$ & $(>) P=.03$ & - & NS & $(>) P=.03$ & $(>) P=.001$ \\
\hline Freestyle & NS & NS & NS & - & NS & $(>) P=.02$ \\
\hline \multicolumn{7}{|l|}{ Bovine xenografts } \\
\hline Pericarbon & NS & NS & $(<) P=.03$ & NS & - & NS \\
\hline Contegra & NS & NS & $(<) P=.001$ & $(<) P=.02$ & NS & - \\
\hline
\end{tabular}

porcine xenografts, including the Freestyle valve, calcify to the same extent as those of homografts. This leaflet calcification, however, remains mild in contrast to the severe calcification found in stented pulmonary valves implanted in the same animal model. ${ }^{6}$ However, calcification in the wall portion of stentless porcine roots was significant. These are most probably due to the typical highly cellularized structure of the aortic wall, which contains more elastin. Obviously none of the antimineralization treatments were able to mitigate the extensive calcifications in the wall portions of the valves, be it $\alpha$-oleic acid, aluminum, or Tween-80. The only significant effect of an antimineralization treatment we could show was that of aluminum preventing pannus formation in the outflow part of the porcine Toronto BiLinx valve.

At present, the basic mechanism of tissue calcification in xenografts is not completely elucidated, but we know that it is determined by many independent factors, such as the age of the recipient, implant position (left or right sided), prosthesis design (stented or stentless), and tissue structure (porcine vs pericardial and wall portion vs cusp). ${ }^{6}$ It is hard to tell which of these factors is the most important in terms of calcification potential, but younger age at implantation will certainly play a major role. Older age at implantation can definitely explain the superior results of RVOT reconstruction during Ross aortic valve replacement in young adults compared with results in those with complex congenital RVOT obstruction. ${ }^{19,20}$

An interesting finding in this series of stented xenografts is their low incidence or even absence of cusp tears. It might of course be related to the decreased pressures in the right side of the heart compared with the left side. On the other hand, it has been suggested that pannus formation on the cusps provides a coating or sheath to the bioprosthetic cusps, thus protecting them from collagen fiber damage that would normally cause tearing. ${ }^{1}$

Cusp immobilization by pannus overgrowth, which is almost classically seen in stented pulmonary site xenografts, leading to so-called open regurgitation, ${ }^{21,22}$ was only found in one of the tested stentless xenografts: the Pericarbon stentless valve. In contrast to the Freestyle, Contegra, and Toronto valves, this valve developed pannus not only at the ventricularis side but also at the fibrosa side, which induced leaflet overgrowth, retraction, and cusp immobilization. It is remarkable that these valves did not calcify at all and showed the lowest calcium contents in all portions. Cusp immobilization reduces stress on the leaflets and the conduit to such an extent that, most probably, calcification of the valves was prevented.

Among the stentless xenografts tested in this series, the bovine jugular vein valved conduit Contegra showed the best results. The cusps remained completely free of calcification and pannus formation, and the degree of conduit calcification was moderate. These results are confirmed by midterm outcome studies in pediatric and adult patients, showing that the durability of the Contegra conduit compares well with that of homografts. ${ }^{23-25}$ However, in some series severe stenosis at the level of the distal anastomosis was reported, leading to reoperation. ${ }^{26,27}$ The origin of this unpredictable incidence of supravalvular stenosis is not yet elucidated. It was never encountered in our experimental model and might be related to the use of surgical techniques or materials to construct the distal anastomosis. Besides the supravalvular stenosis, wall calcification was found in early to midterm human explants. ${ }^{27}$

In summary, this experimental study clearly shows the superiority of pulmonary over aortic homografts for RVOT reconstruction. Stentless porcine xenografts and the bovine jugular vein conduit are acceptable alternatives because they have low cusp calcification and no leaflet tearing or cusp immobilization. However, significant wall calcification develops in spite of any anticalcification treatment.

\section{References}

1. Soor GS, Leong SW, Butany J, Shapero JL, Williams WG. Pulmonary site bioprostheses: morphologic findings in 40 cases. Arch Pathol Lab Med. 2009; 133:797-802. 
2. Ross DN, Somerville J. Correction of pulmonary atresia with a homograft aortic valve. Lancet. 1966;2:1446-7.

3. Niwaya K, Knott-Craig CJ, Lane MM, Chandrasekaren K, Overholt ED, Elkins RC. Cryopreserved homograft valves in the pulmonary position: risk analysis for intermediate-term failure. J Thorac Cardiovasc Surg. 1999;117:141-6.

4. Tweddell JS, Pelech AN, Frommelt PC, Mussatto KA, Wyman JD, Fedderly RT, et al. Factors affecting longevity of homograft valves used in right ventricular outflow tract reconstruction for congenital heart disease. Circulation. 2000; 102(suppl III):III130-5.

5. Goffin YA, Van Hoeck B, Jashari R, Soots G, Kalmar P. Banking of cryopreserved heart valves in Europe: assessment of a 10-year operation in the European Homograft Bank (EHB). J Heart Valve Dis. 2000;9:207-14.

6. Flameng W, Meuris B, Yperman J, De Visscher G, Herijgers P, Verbeken E. Factors influencing calcification of cardiac bioprostheses in adolescent sheep. J Thorac Cardiovasc Surg. 2006;132:89-98

7. Jashari R, Van Hoeck B, Tabaku M, Vanderkelen A. Banking of the human heart valves and the arteries at the European homograft bank (EHB)-overview of 14-year activity in this International Association in Brussels. Cell Tissue Bank. 2004;5:239-51

8. Meyns BR, Jashari R, Gewillig M, Mertens L, Komárek A, Lesaffre E, et al. Factors influencing the survival of cryopreserved homografts. The second homograft performs as well as the first. Eur J Cardiothorac Surg. 2005;28:211-6.

9. Homann M, Haehnel JC, Mendler N, Paek SU, Holper K, Meisner H, et al. Reconstruction of the RVOT with valved biological conduits: 25 years of experience with allografts and xenografts. Eur J Cardiothorac Surg. 2000;17:624-30.

10. Perron J, Moran AM, Gauvreau K, del Nido JE Jr, Jonas RA. Valved homograft conduit repair of the right heart in early infancy. Ann Thorac Surg. 1999;68: $542-8$.

11. Flameng W, Herregods MC, Vercalsteren M, Herijgers P, Bogaerts K, Meuris B. Prosthesis-patient mismatch predicts structural valve degeneration in bioprosthetic heart valves. Circulation. 2010;121:2123-9.

12. Hopkins RA, Jones AL, Wolfingbarger L, Moore M, Bert AA, Lofland GK. Decellularization reduces calcification while improving both durability and 1-year functional results of pulmonary homograft valves in juvenile sheep. $J$ Thorac Cardiovasc Surg. 2009; 137:907-13.

13. Clarke DR, Bishop DA. Allograft degeneration in infant pulmonary valve allograft recipients. Eur J Cardiothorac Surg. 1993;7:365-70.

14. Yuan SM, Mishaly D, Shinfeld A, Raanani E. Right ventricular outflow tract reconstruction: valved conduit of choice and clinical outcomes. J Cardiovasc Med (Hagerstown). 2008;9:327-37.
15. Belli E, Salihoglu E, Leobon B, Roubertie F, Ly M, Roussin R, et al. The performance of Hancock porcine-valved Dacron conduit for right ventricular outflow tract reconstruction. Ann Thorac Surg. 2010;89:152-7.

16. Kanter KR, Fyfe DA, Mahle WT, Forbess JM, Kirshbom PM. Results with the Freestyle porcine aortic root for right ventricular outflow tract reconstruction in children. Ann Thorac Surg. 2003;76:1889-94.

17. Hartz RS, Deleon SY, Lane J, Dorotan J, Joyce J, Urbina E, et al. Medtronic freestyle valves in right ventricular outflow tract reconstruction. Ann Thorac Surg. 2003;76:1896-900.

18. Erez E, Tam VK, Doublin NA, Stakes J. Repeat right ventricular outflow tract reconstruction using the Medtronic Freestyle porcine aortic root. J Heart Valve Dis. 2006; 15:92-6.

19. Bilal MS, Aydemir NA, Cine N, Turan T, Yildiz Y, Yalcin Y, et al. Intermediateterm results of Medtronic freestyle valve for right ventricular outflow tract reconstruction in the Ross procedure. J Heart Valve Dis. 2006;15:696-701.

20. Brown JW, Ruzmetov M, Rodefeld MD, Turretine MW. Right ventricular outflow tract reconstruction in Ross patients: does the homograft fare better? Ann Thorac Surg. 2008;86:1607-12.

21. Schmid FX, Keyser A, Wiesenack C, Holmer S, Birnbaum DE. Stentless xenografts and homografts for right ventricular outflow tract reconstruction during the Ross operation. Ann Thorac Surg. 2002;74:684-8.

22. Murphy SK, Rogler WC, Fleming WH, McManus BM. Retraction of bioprosthetic heart valve cusps: a cause of wide-open regurgitation in right-sided heart valves. Hum Pathol. 1988;19:140-7.

23. Breymann T, Blanz U, Wojtalik MA, Daenen W, Hetzer R, Sarris G, et al. European Contegra multicentre study: 7-year results after 165 valved bovine jugular vein graft implantations. Thorac Cardiovasc Surg. 2009;57:257-69.

24. Boethig D, Thies WR, Hecker H, Breymann T. Mid term course after pediatric right ventricular outflow tract reconstruction: a comparison of homografts, porcine xenografts and Contegras. Eur J Cardiothorac Surg. 2005; 27:58-66.

25. Niclauss L, Delay D, Hurni M, von Segesser LK. Experience and intermediateterm results using the Contegra heterograft for right ventricular outflow reconstruction in adults. Interact Cardiovasc Thorac Surg. 2009;9:667-71.

26. Göber V, Berdat P, Pavlovic M, Pfammatter JP, Carrel TP. Adverse mid-term outcome following RVOT reconstruction using the Contegra valved bovine jugular vein. Ann Thorac Surg. 2005;79:625-31.

27. Meyns B, Van Garsse L, Boshoff D, Eyskens B, Mertens L, Gewillig M, et al. The Contegra conduit in the right ventricular outflow tract induces supravalvular stenosis. J Thorac Cardiovasc Surg. 2004;128:834-40. 